\title{
Erratum zu: Effi Briest-Handbuch
}

\section{Stefan Neuhaus (Hg.)}

\section{Erratum zu: \\ Die Online-Version in: S. Neuhaus (Hg.), Effi Briest-Handbuch, https://doi.org/10.1007/978-3-476-04874-5}

Die Namen der Kapitelautoren wurden online korrigiert.

Dort standen anfangs überall die Namen der Herausgeber.

Die korrigierte Online-Version dieses Buches finden Sie unter https://doi.org/10.1007/978-3-476-04874-5 